\title{
KELIMPAHAN DAN KOMPOSISI JENIS IKAN HASIL TANGKAPAN BUBU DI PERAIRAN GUGUSAN PULAU KELAPA KEPULAUAN SERIBU
}

\author{
Sri Turni Hartati"), Awwaluddin"), dan Indar Sri Wahyuni")
}

\begin{abstract}
ABSTRAK
Perairan gugusan Pulau Kelapa, Kepulauan Seribu merupakan salah satu kawasan terumbu karang Sebagian dari aktivitas penduduknya melakukan usaha penangkapan ikan dengan alat tangkap bubu. Penelitian yang dilakukan selama 5 bulan dari April sampai Oktober 2003 bertujuan untuk memperoleh data dan informasi tentang hasil tangkapan bubu, yang dipasang di terumbu karang dengan kondisi bervariasi (kondisi sedang-buruk). Penelitian dilakukan dengan cara mengikuti kegiatan nelayan bubu di 25 lokas daerah penangkapan (fishing ground). Untuk kelengkapan data dilakukan wawancara dengan nelayan dan pedagang pengumpul setempat. Hasil penelitian menunjukkan bahwa tangkapan bubu terdiri dari 37 jenis yang di dominasi oleh ikan pasir (Scolopsis sp.=21,92\%), swangi (Sargocentron=13,08\%), kelompok ikan kerapu (Grouper=12,31\%), dan ikan ekor kuning (Caesio sp. $=10,77 \%$ ) sedangkan komposisi jenis ikan lainnya berada di bawah 10\%. Kelompok ikan kerapu (Grouper: Ephinephelus sp., Cephalopholis sp., dan Plectropomus sp.) yang merupakan target atau tangkapan utama, produksinya mencapai 6-30 ton per tahun.
\end{abstract}

\section{ABSTRACT: Abundance and composition of fish yield captured by fishing traps in Kelapa Island} waters, Seribu Islands. By: Sri Turni Hartati, Awwaluddin, and Indar Sri Wahyuni

\begin{abstract}
Kelapa Island waters in Seribu Islands is one of the coral reef parts where some of fishermen use fishing traps in their fishing activities. The research on fishing traps in this area was carried out during 5 months from April to October 2003. The aim of the research is to collect data and information on catch of fishing traps deploying in various coral reef conditions (middle-to bad conditions). The research was done by following the fishermen who are fishing by using traps in about 25 locations, and interview of some fishermen to complete data and information needed. The results show the catch consisted of 38 species with dominant species such as: Scolopsis sp. (21.92\%), Sargocentron sp. (13.08\%), Groupers (12.31\%), and Caesio sp. (10.77\%). Groupers (Ephinephelus sp., Cephalopholis sp., and Plectropomus sp.) are the main target of fish captured that usually fishermen kept a live to obtain the highest price possible of the fish. At the present time the production can reach a value of 6-30 tons for year.
\end{abstract}

KEYWORDS: $\quad$ abundance, trap, catch, Seribu Islands

\section{PENDAHULUAN}

Sebagai negara kepulauan terbesar di dunia yang memiliki wilayah laut sangat luas, Indonesia memiliki sumber daya alam hayati laut yang melimpah. Salah satu sumber daya alam tersebut adalah ekosistem terumbu karang. Luas terumbu karang Indonesia lebih kurang $60.000 \mathrm{~km}^{2}$ atau satu per delapan dari luas total yang terdapat di belahan dunia (Dahuri, 2000).

Ekosistem terumbu karang memiliki berbagai fungsi, seperti ekologi, ekonomi, fisik, dan estetika (Lazuardi \& Wijoyo, 1999). Dari segi ekonomi terumbu karang menjadi sumber kehidupan bagi beranekaragam biota laut, yaitu terdapat lebih dari 200 jenis ikan dan berpuluh-puluh jenis moluska, krustasea, sponge, algae, dan biota laut lainnya. Keberadaan beranekaragam biota laut tersebut akan mempengaruhi penghasilan nelayan di sekitarnya.

Kepulauan Seribu terletak di bagian barat Laut Jawa, beberapa wilayah perairannya merupakan ekosistem terumbu karang. Salah satu diantaranya adalah Perairan Gugusan Pulau Kelapa, yang mempunyai arti sangat penting bagi masyarakat setempat. Umumnya nelayan di daerah ini melakukan aktivitas penangkapan ikan di sekitar Perairan Pulau Kotok, Pulau Pamegaran, Pulau Panjang Kecil, Pulau Putri, daerah Karang Pasangan Tuan, dan Karang Bongkok.

Salah satu aktivitas nelayan Pulau Seribu adalah melakukan penangkapan ikan dengan alat tangkap bubu. Bubu merupakan alat penangkapan yang berupa jebakan, sifatnya pasif dan biasanya terbuat dari anyaman bambu, rotan ataupun kawat. Kelebihan bubu dari alat tangkap lainnya adalah harga relatif lebih murah, kualitas hasil tangkapan hidup lebih besar dan cenderung tidak merusak lingkungan.

Alat tangkap bubu yang dioperasikan nelayan Pulau Kelapa adalah bubu dasar yang dipasang di Perairan Karang atau diantara karang dan bebatuan. Hasil tangkapan bubu umumnya mempunyai kualitas baik, jenis-jenis yang tertangkap diantaranya adalah jenis kuwe (Caranx spp.), baronang (Siganus spp.), kerapu (Ephinephelus spp. dan Cephalopholis spp.), kakap (Lutjanus spp.), kakaktua (Scarus spp.), ekorkuning (Caesio spp.), lencam (Lethrinus spp.), dan biota laut lainnya seperti udang penaeid, udang barong dan lain lain (Subani, 1988).

*) Peneliti pada Balai Riset Perikanan Laut, Jakarta 
Tujuan penelitian ini adalah untuk memperoleh data dan informasi tentang kelimpahan dan komposisi jenis hasil tangkapan bubu di Perairan Gugusan Pulau Kelapa, sehubungan dengan menurunnya kondisi terumbu karang di kawasan tersebut berdasarkan hasil penelitian yang telah dilakukan sebelumnya.

\section{BAHAN DAN METODE}

Penelitian dilakukan di Perairan Gugusan Pulau Kelapa dan sekitarnya (Gambar 1), pada bulan April, Mei, Juli, Agustus, dan Oktober 2003. Perolehan data hasil tangkapan bubu dilakukan dengan cara mengikuti kegiatan nelayan di 25 lokasi penangkapan (fishing ground) yang dianggap sebagai stasiun penelitian. Setiap lokasi penangkapan dipasang 2 buah bubu dan diangkat setelah 2 hari. Identifikasi jenis ikan hasil tangkapan mengacu kepada beberapa referensi seperti "Trawled Fishes of Southern Indonesia and Northwestern Australia" (Gloerfelt-Tarp \& Kailola); "Groupers of The World" (Heemstra \& Randall, 1993); "Tropical Reef-Fishes of the Western Pacific" (Kuiter, 1992); dan "The Marine Fishery Resources of Sri Lanka" (FAO, 1994).

Pengamatan kondisi lingkungan perairan di lokasi penangkapan juga dilakukan, meliputi kedalaman perairan $(\mathrm{m})$, kecerahan $(\mathrm{m})$, suhu $\left({ }^{\circ} \mathrm{C}\right)$, salinitas $\left({ }^{\circ} \% o\right)$, $\mathrm{pH}, \quad \mathrm{DO}\left(\mathrm{ml}^{-1}\right)$, kecepatan arus $\left(\mathrm{m} \operatorname{detik}^{-1}\right)$, dan kecepatan angin $\left(m\right.$ detik $\left.^{-1}\right)$.
Data kondisi terumbu karang di perairan Gugusan Pulau Kelapa dan sekitarnya mengacu pada hasil penelitian yang dilakukan oleh Lazuardi \& Wijoyo (1999). Data tentang aspek perikanan bubu lainnya diperoleh berdasarkan wawancara dengan nelayan bubu setempat dan pedagang pengumpul hasil tangkapan.

\section{HASIL DAN BAHASAN}

\section{Spesifikasi Alat Tangkap Bubu}

Alat tangkap bubu yang dioperasikan di Perairan Gugusan Pulau Kelapa dan sekitarnya adalah bubu dasar. Desain dan konstruksi bubu dibuat sendiri oleh masing-masing nelayan dan biasanya seragam. Bubu yang digunakan terbuat dari anyaman kawat baja, berbentuk empat persegi panjang, dengan ukuran (tinggi $x$ lebar $x$ panjang) adalah $(27 \times 33 \times 153)$ mata per $2 \mathrm{~cm}^{2}$. Bubu terdiri dari bagian badan, mulut, dan pintu. Mulut bubu berbentuk kerucut, bagian luar mempunyai diameter lebih besar dan semakin menyempit ke arah dalam. Pintu bubu berada di bagian bawah bubu yang berfungsi untuk mengambil hasil tangkapan dari dalam bubu. Model atau tipe bubu yang biasa dioperasikan di Perairan Gugusan Pulau Kelapa dan sekitarnya disajikan (Gambar 2).

\section{Operasional dan Daerah Penangkapan}

Kegiatan penangkapan ikan dengan bubu dilakukan di beberapa daerah fishing ground dengan

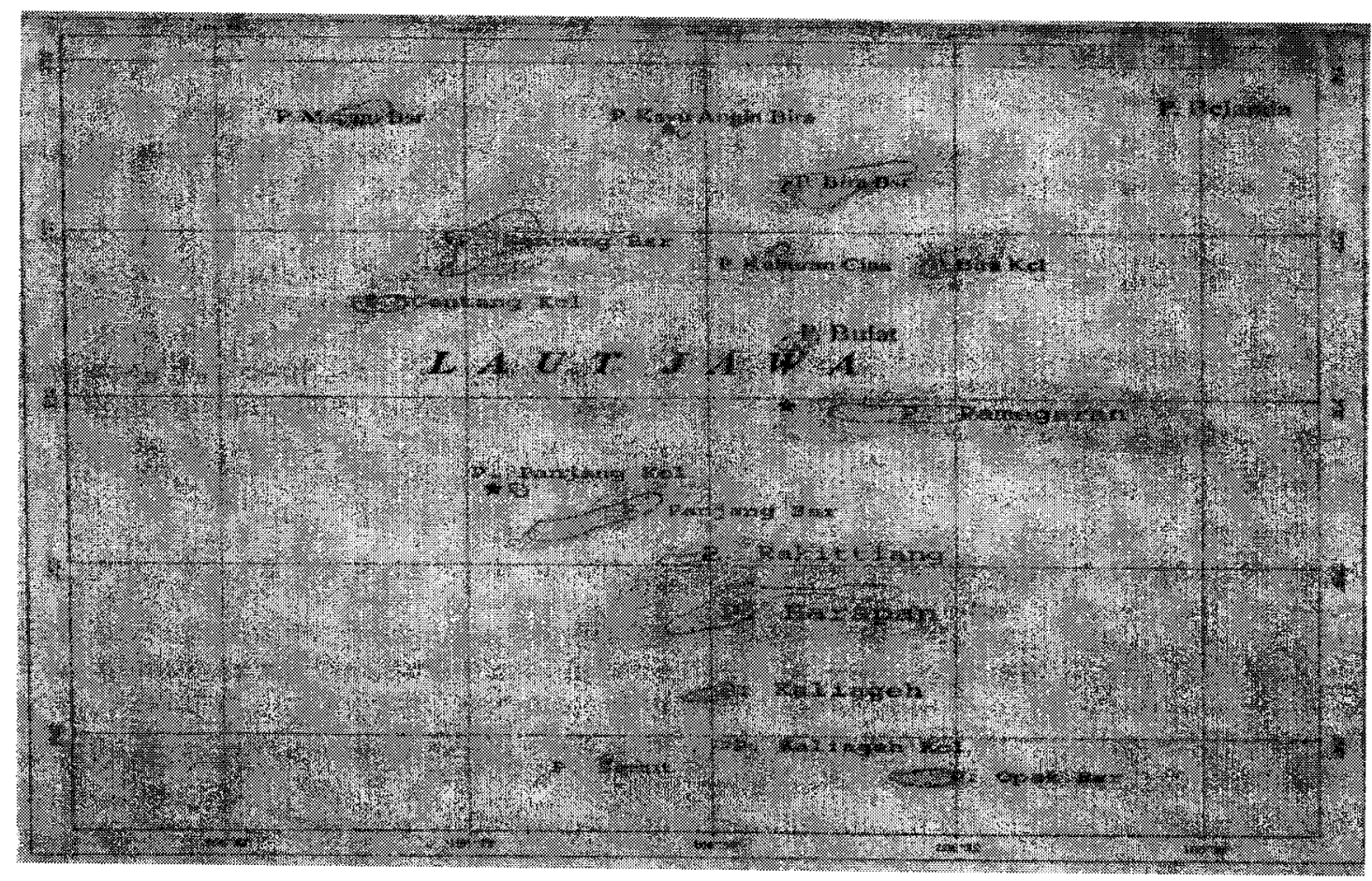

Gambar 1. Lokasi pengamatan bubu di perairan Pulau Kelapa dan sekitarnya.

Figure. 1. Research location of fishing traps in Kelapa Island waters and Adjacent. 


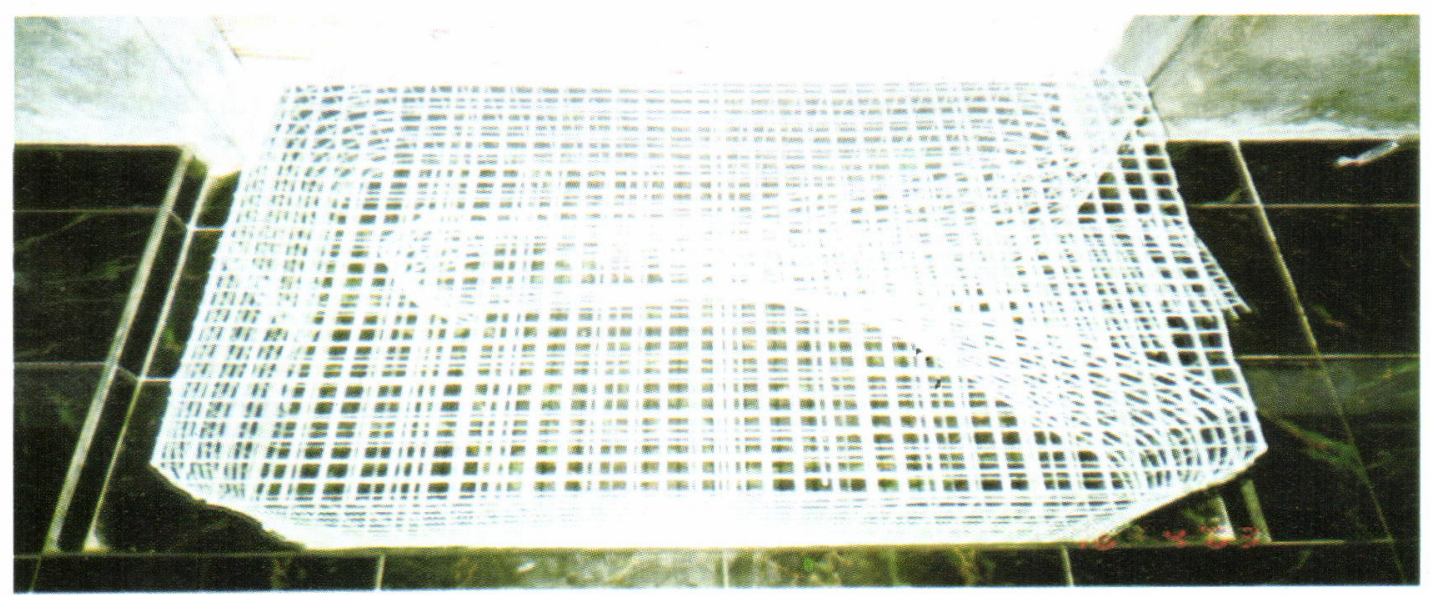

Gambar 2. Desain bubu yang digunakan nelayan Pulau Kelapa.

Figure. 2. Design of trap which used by Kelapa Island's fishermen.

menggunakan perahu. Satu kelompok nelayan biasanya beranggotakan 3-5 orang dengan jumlah bubu berkisar antara 20-24 buah. Bubu dipasang pada perairan yang berkarang, kemudian ditimbun atau ditindih dengan menggunakan batuan karang mati agar tidak bergeser sekaligus untuk penyamaran. Bubu di pasang selama 2 hari dan di dalamnya diberi umpan berupa cacahan ikan. Biasanya, untuk satu lokasi dipasang 2 buah bubu. Bubu yang satu dengan lainnya tidak dirangkai dengan tali (tunggal). Untuk menghindari pencurian bubu, penandaan lokasi pemasangan tidak dilakukan dengan pemasangan bendera atau pelampung, tetapi dengan cara baringan yaitu menggunakan tanda-tanda alam yang ada dari pulau-pulau di sekitarnya. Hasil tangkapan diusahakan untuk tetap hidup, dengan cara ditampung di dalam bak-bak berukuran besar dan diberi aerator.

Daerah penangkapan bubu di Perairan Gugusan Pulau Kelapa dan sekitarnya diantaranya adalah
Pulau Kotok, Pulau Putri, Pulau Belokan, Pulau Gama, Pulau Bira, Pulau Dua, Pulau Jagung, Pulau Penjaliran, dan lainnya. Kedalaman daerah penangkapan mencapai $30 \mathrm{~m}$, sehingga dalam pemasangan dan pengangkatan bubu dilakukan dengan cara penyelaman menggunakan alat bantu kompresor (Gambar 3).

\section{Kelimpahan dan Komposisi Hasil Tangkapan}

Hasil tangkapan bubu yang di pasang pada 25 lokasi penangkapan lebih kurang 37 jenis ikan karang dengan jumlah 260 ekor. Kelimpahan dan komposisi jenis ikan hasil tangkapan bubu disajikan pada Lampiran 1. Hasil tangkapan ikan pada setiap stasiun pengamatan berkisar antara 0-41 ekor per 2 bubu. Hasil tangkapan relatif banyak diperoleh di stasiun 9 10, dan 25, berturut-turut 30 ekor per 2 bubu, 41 ekor per 2 bubu, dan 31 ekor per 2 bubu. Kelompok ikan kerapu atau Groupers (Plectropomus sp., Plectropomus sp., Cephalopholis sp., dan

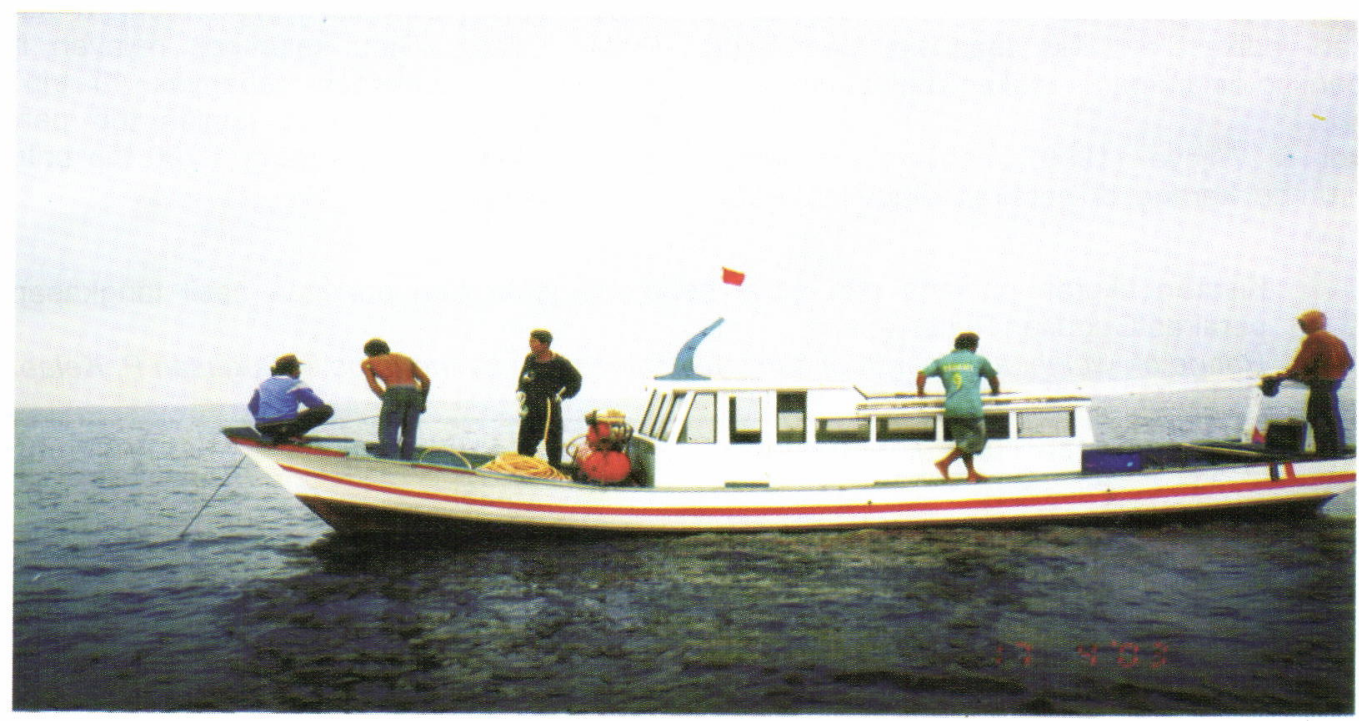

Gambar 3

Proses penyelaman pada pengoperasian alat tangkap bubu.

Figure. 3. Diving processes in fishing traps operation. 
Ephinephelus sp.) yang nilai pasarannya relatif tinggi terutama dalam kondisi hidup, hasil tangkapan mencapai 6-30 ton per tahun. Hasil tangkapan bubu didominasi oleh jenis ikan pasir-pasir (Scolopsis sp.), swangi (Sargocentron sp.), kerapu (Cephalopholis sp, Plectropomus sp., Ephinephelus sp.), dan ekor kuning (Caesio sp.) masing-masing sebesar 21,92\%; $13,08 \% ; 12,31 \%$, dan $10,77 \%$.

Kisaran ukuran panjang dan berat beberapa jenis ikan dominan disajikan pada Tabel 1. Ukuran ikan yang tertangkap pada umumnya relatif kecil. Sebaran ukuran kelompok ikan kerapu (Cephalopholis sp., Ephinephelus sp., dan Plectropomus sp.) mempunyai panjang berkisar antara $13-34 \mathrm{~cm}$ dan berat berkisar antara 50-500 gram. Implikasi dari sebaran panjang dan berat dengan membandingkan ukuran yang umum tertangkap di perairan Indonesia, terutama kelompok ikan kerapu yaitu berat di atas 500 gram dan panjang di atas $30 \mathrm{~cm}$, mengindikasikan bahwa pada lokasi contoh terdapat tekanan penangkapan dan dapat dikatakan ada kecenderungan lebih tangkap (over fishing).

Jenis ikan yang bernilai ekonomis tinggi seperti kerapu (Grouper), lencam (Lethrinus sp.), dan kakap (Lutjanus sp.) banyak tertangkap di stasiun 9 dengan posisi geografis $05^{\circ} 35^{\prime} 47,6^{\prime \prime}$ Lintang Selatan dan $106^{\circ} 33^{\prime} 03,9^{\prime \prime}$ Bujur Timur. Beberapa contoh ikan yang tertangkap dengan bubu disajikan pada Gambar 4.

\section{Kondisi Lingkungan Perairan}

Terumbu karang di Kepulauan Seribu pada umumnya merupakan karang tepi (fringing reef) dan geomorfologinya di pengaruhi pantai. Rataan terumbu dan tubir bagian atas pada umumnya didominasi oleh Acropora dan Montipora. Berdasarkan penelitian yang dilakukan oleh Giyanto \& Soekarno (1977) bahwa semakin dekat jarak terumbu karang dengan daratan Pulau Jawa, kondisi terumbu semakin buruk. Hal ini memberikan indikasi aktivitas manusia memegang peranan penting dalam pengrusakan lingkungan.

Lazuardi \& Wijoyo (1999) menyatakan bahwa kondisi terumbu karang di perairan Gugusan Pulau
Kelapa dan sekitarnya termasuk ke dalam kategori sedang sampai buruk. Kondisi terumbu karang dalam kategori sedang artinya bahwa persentase penutupan karang hidup berkisar antara $25-49,9 \%$, sedangkan kategori buruk hanya berkisar antara $0-24,9 \%$

Kondisi terumbu karang di perairan Gugusan Pulau Kelapa pada umumnya tidak jauh berbeda dengan perairan lain di Indonesia. Seperti misalnya di perairan Teluk Saleh terumbu karang dalam kategori buruk sampai sedang dengan persentase tutupan karang hidup berkisar antara 10\%-50\% (Hartati, et. al., 2004). Hasil tangkapan ikan di Perairan Teluk Saleh berkisar antara 144-322 ekor per hari. Dengan melihat bahwa kelimpahan ikan karang di Perairan Teluk Saleh relatif lebih tinggi, menguatkan dugaan bahwa di Perairan Gugusan Pulau Kelapa telah terjadi tekanan penangkapan yang menyebabkan keadaan over fishing.

Kondisi terumbu karang di perairan Gugusan Pulau Kelapa dan sekitarnya disajikan dalam Tabel 2, Tabel 3, Gambar 5, dan Gambar 6.

Nilai keseluruhan parameter lingkungan pada stasiun pengamatan masih dalam batasan normal untuk kehidupan biota karang. Salinitas berkisar antara $32,0-33,0 \%$, suhu $30,11-30,36^{\circ} \mathrm{C}, \mathrm{pH}$ berkisar antara 7,14-7,19 dan oksigen terlarut 4,03-4,12 $\mathrm{ml} \mathrm{l}^{-1}$. Seluruh lokasi penangkapan yang ditentukan sebagai stasiun pengamatan kecerahannya relatif tinggi, yaitu berkisar antara 10,7-19,6 m. Data kondisi lingkungan perairan disajikan pada Lampiran 2.

\section{Produksi}

Usaha perikanan bubu di Gugusan Pulau Kelapa dan sekitarnya berlangsung sepanjang tahun (tidak mengenal musim). Jumlah nelayan bubu yang pada saat ini masih aktif melakukan usaha penangkapan sebanyak 10 kelompok yang semuanya berdomisili di Pulau Kelapa. Satu kelompok nelayan melakukan kegiatan penangkapan sebanyak 10 trip dalam 1 bulan. Dengan demikian jumlah trip penangkapan dalam 1 tahun lebih kurang 1.200 trip untuk seluruh kelompok nelayan

Tabel 1. Kisaran ukuran panjang dan berat beberapa jenis ikan dominan hasil tangkapan bubu di perairan Gugusan Pulau kelapa

Table 1. Range of weight and length of dominant fish caught by the traps in Gugusan P. Kelapa waters

\begin{tabular}{lccc}
\hline No. Jenis Ikan Dominan/Dominant spesies & Panjang/Length $(\mathbf{c m})$ & Berat/Weight (gr) \\
\hline 1 & Caesio sp & $15-23$ & $125-210$ \\
2 & Cephalopholis sp & 20 & 210 \\
3 & Ephinephelus sp & $13-26$ & $50-270$ \\
4 & Plectropomus sp & $21-34$ & $110-550$ \\
5 & Sargocentron sp & $11-16.5$ & $40-100$ \\
6 & Scolopsis sp & $15-25$ & $50-140$ \\
\hline
\end{tabular}




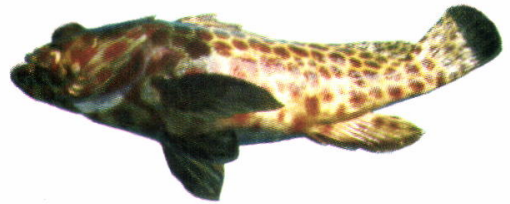

Ephinephelus quoyanus

(kerapu lokal)

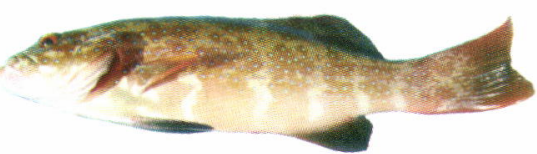

Plectropomus maculatus

(kerapu lodi)

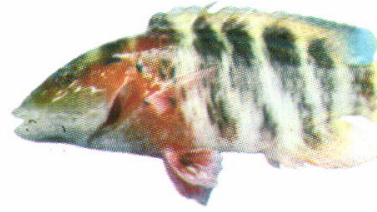

Cheilinus fasciatus

(nuri)

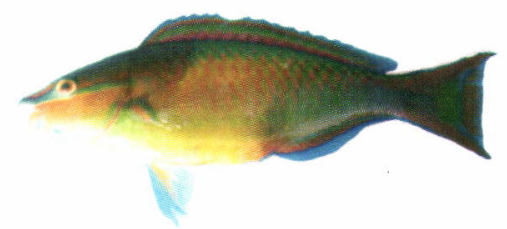

Scarus forsteni

(kakak tua)

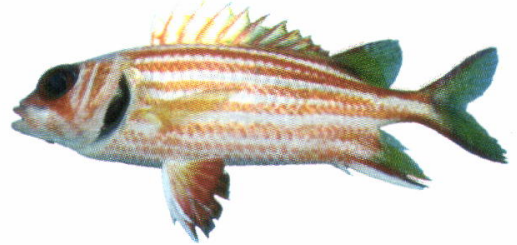

Sargocentron ittodai (swangi)

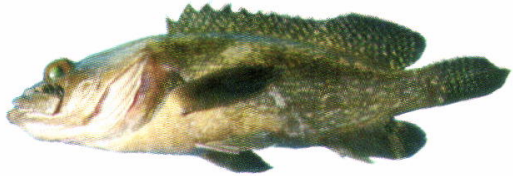

Ephinephelus ongus

(kerapu lokal)

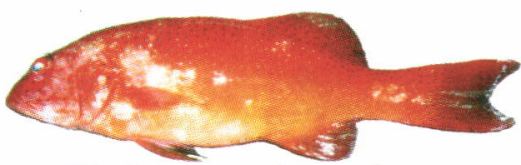

Plectropomus leopardus

(sunu halus)

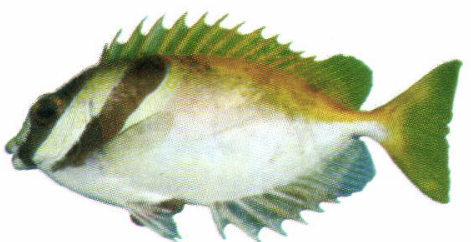

Siganus virgatus

(kea-kea)

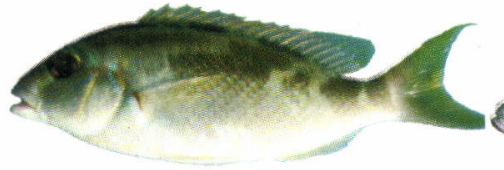

Scolopsis taeniopterus

(pasir)

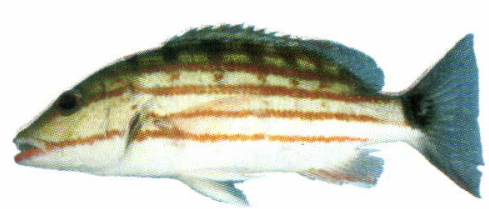

Lutjanus decussatus

(tanda-tanda)

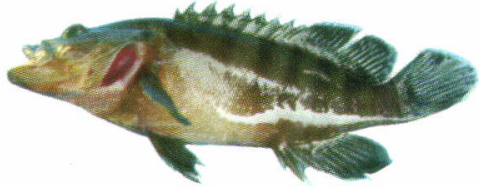

Cephalopholis boenak (kerapu batu)

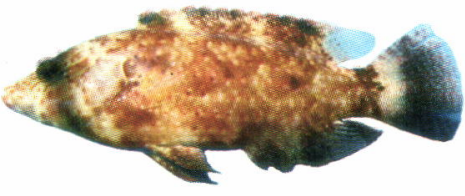

Cheilinus chlorourus (nuri hitam)

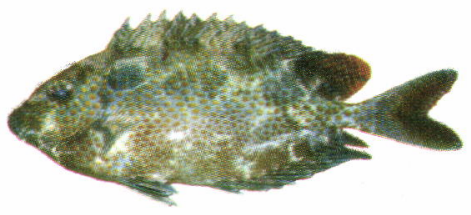

Siganus guttatus (baronang)

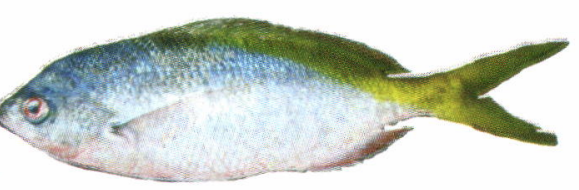

Caesio erithrogaster (ekor kuning)

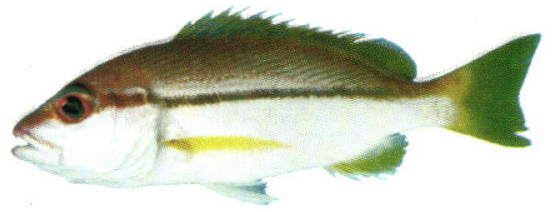

Lutjanus vittus (kalalau)

Gambar 4. Komposisi hasil tangkapan dengan alat tangkap bubu di Gugusan Pulau Kelapa. Figure 4. Species composition caught by traps in Kelapa Island waters. 
Tabel 2. Persen penutupan karang hidup pada kedalaman 3 meter Table 2. Percentage of living coral cover in 3 meters of depth

\begin{tabular}{ccccc}
\hline $\begin{array}{c}\text { Stasiun } \\
\text { Station }\end{array}$ & $\begin{array}{c}\text { Karang Batu } \\
\text { Stone Coral }\end{array}$ & $\begin{array}{c}\text { Karang Lunak } \\
\text { Soft Coral }\end{array}$ & Total & $\begin{array}{c}\text { Kategori } \\
\text { Categorie }\end{array}$ \\
\hline 1 & 21,20 & 0,00 & 21,20 & Buruk \\
2 & 36,00 & 0,80 & 36,80 & Sedang \\
Buruk \\
3 & 16,00 & 2,10 & 18,10 & Sedang \\
4 & 46,76 & 1,00 & 47,76 & Sedang \\
5 & 45,70 & 0,40 & 46,90 & Sedang \\
6 & 28,70 & 0,00 & 29,10 & Sedang \\
7 & 41,60 & 4,20 & 41,60 & Sedang \\
8 & 23,90 & 0,00 & 28,10 & Buruk \\
9 & 14,58 & 0,00 & 14,58 & Sedang \\
10 & 26,10 & 0,40 & 26,10 & Buruk \\
11 & 4,80 & 0,00 & 5,20 & Sedang \\
12 & 34,20 & 0,00 & 34,20 & Buruk \\
13 & 15,22 & 1,10 & 16,32 & Buruk \\
14 & 8,30 & 0,00 & 8,30 & Sedang \\
15 & 39,36 & 4,26 & 43,62 & Buruk \\
\hline
\end{tabular}

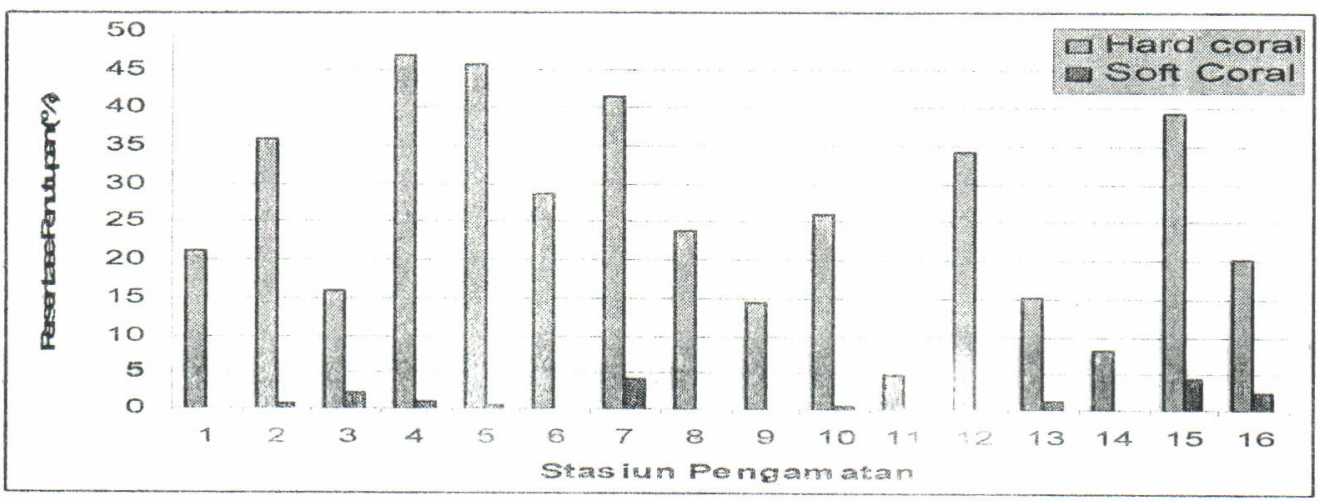

Gambar 5. Persen penutupan karang batu dan karang lunak pada kedalaman 3 meter. Figure 5. Percentage of stone coral and soft coral cover in 3 meters depth.

Tabel 3. Persen penutupan karang di kedalaman 10 meter

Table 3. Percentage of coral cover in 10 meters clepth

\begin{tabular}{|c|c|c|c|c|}
\hline $\begin{array}{l}\text { Stasiun } \\
\text { Station }\end{array}$ & $\begin{array}{l}\text { Karang Batu } \\
\text { Stone Coral }\end{array}$ & $\begin{array}{c}\text { Karang Lunak } \\
\text { Soft Coral }\end{array}$ & Total & $\begin{array}{l}\text { Kategori } \\
\text { Categorie }\end{array}$ \\
\hline 1 & 18,80 & 1,80 & 20,60 & Buruk \\
\hline 2 & 20,64 & 0,00 & 20,64 & Buruk \\
\hline 3 & 11,40 & 13,10 & 24,50 & Buruk \\
\hline 4 & 28,20 & 1,40 & 29,60 & Sedang \\
\hline 5 & 4.60 & 33,80 & 38,40 & Sedang \\
\hline 6 & 17.80 & 10,40 & 28,20 & Sedang \\
\hline 7 & 17.80 & 0,00 & 17,80 & Buruk \\
\hline 8 & 25,40 & 15,50 & 40,90 & Sedang \\
\hline 9 & 31,10 & 0,00 & 31,10 & Sedang \\
\hline 10 & 19,90 & 0,00 & 19,90 & Buruk \\
\hline 11 & 12,40 & 7,00 & 19,40 & Buruk \\
\hline 12 & 2,40 & 4,00 & 6,40 & Buruk \\
\hline 13 & 16,00 & 0,00 & 16,00 & Buruk \\
\hline 14 & 12,70 & 2,60 & 15,30 & Buruk \\
\hline 15 & 28,90 & 2,60 & 31,50 & Sedang \\
\hline 16 & 20,90 & 0,90 & 21,80 & Buruk \\
\hline
\end{tabular}




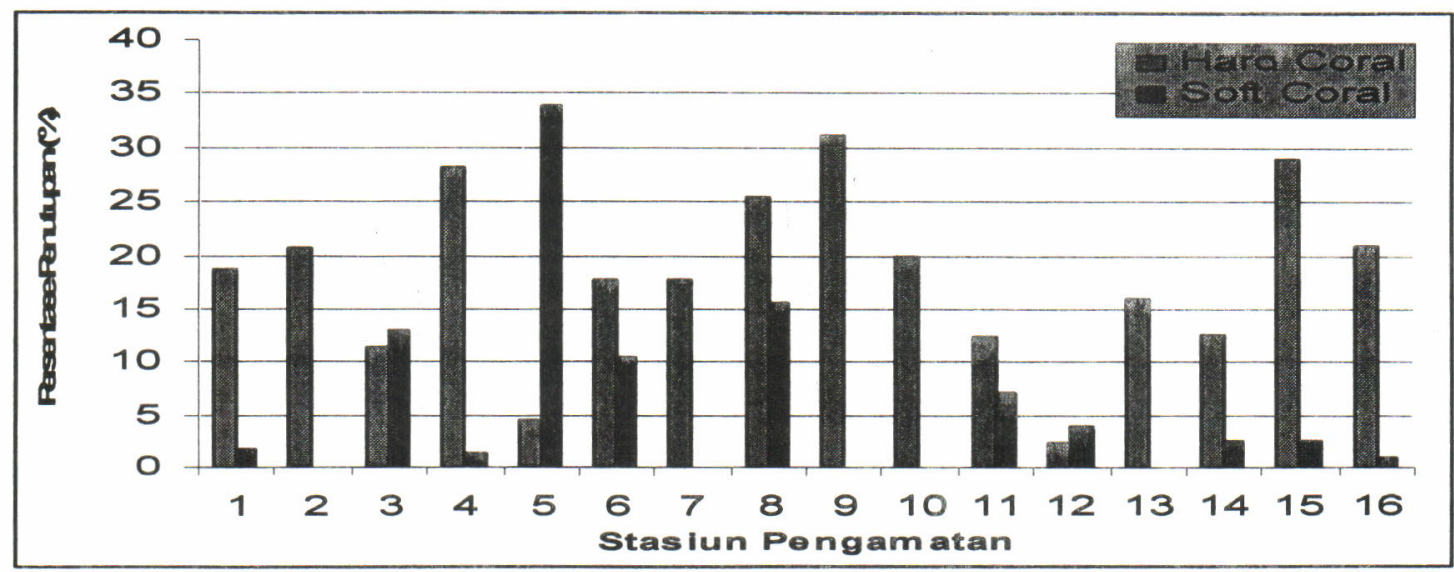

Gambar 6. Persen penutupan karang batu dan karang lunak pada kedalaman 10 meter.

Figure 6. Percentage of stone coral and soft coral cover in 10 meters depth.

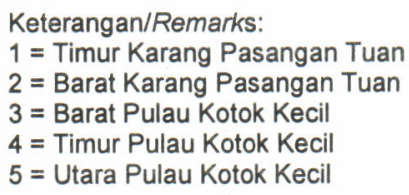

\begin{abstract}
11 = Timur Pulau Panjang Kecil 12 = Barat Pulau Panjang Kecil 13 = Timur Karang Bongkok 14 = Selatan Karang Bongkok 15 = Utara Karang Bongkok $16=$ Barat Karang Bongkok
\end{abstract}

Hasil tangkapan utama atau target adalah ikan kerapu hidup. Setiap kelompok nelayan dalam setiap trip penangkapan dapat memperoleh hasil tangkapan antara $5-25 \mathrm{~kg}$ ikan kerapu. Dari data tersebut dapat diperkirakan bahwa produksi ikan kerapu dari perairan Gugusan Pulau Kelapa berkisar antara 6-30 ton per tahun. Hasil tangkapan selain ikan kerapu tidak dipasarkan, tetapi dibagi untuk anggota kelompok.

\section{KESIMPULAN}

1. Hasil tangkapan bubu di Perairan Gugusan Pulau kelapa, Kepulauan Seribu terdiri dari 38 jenis yang didominasi oleh ikan pasir-pasir (Scolopsis sp. $=21,92 \%$ ), swangi (Sargocentron sp.=13,08\%), kelompok ikan kerapu (Grouper=12,31\%), dan ikan ekor kuning (Caesio sp.=10,77\%).

2. Hasil tangkapan ikan kerapu (groupers) yang merupakan target atau tangkapan utama mencapai 6-30 ton per tahun.

3. Jenis ikan yang bernilai ekonomis tinggi seperti kerapu (Grouper), lencam (Lethrinus sp.), dan kakap (Lutjanus sp.) banyak tertangkap di stasiun 9 dengan posisi geografis $05^{\circ} 35^{\prime} 47,6^{\prime \prime}$ Lintang Selatan dan $106^{\circ} 33^{\prime} 03,9^{\prime \prime}$ Bujur Timur.

\section{DAFTAR PUSTAKA}

Dahuri, R. 2000. Kebijakan dan strategi pengelolaan terumbu karang Indonesia. Prosiding Lokakarya Pengelolaan dan IPTEK Terumbu Karang Indonesia. LIPI-COREMAP. Jakarta. (hal: 16).

De Bruin, G.H.P., B.C. Russel, \& A. Bogusch. 1994. The marine fishery resource of Sri Lanka.
FAO Species Identification Field Guide For Fishery Purposes.

Giyanto \& Soekarno. 1997 Perbandingan komunitas terumbu karang pada dua kedalaman dan empat zona yang berbeda di Pulau-pulau Seribu Jakarta. Oseanologi dan Limnologi di Indonesia. No. 30: 33-51.

Gloerfelt-Tarp, T. \& P.J. Kailola. Trawled fishes of Southern Indonesia and Northwestern Australia. Australian Development Assistance Bureau; Directorate General of Fisheries of Indonesia and German Agency for Technical Cooperation. National Library of Australia.

Hartati, S.T., Awwaluddin, \& R. Puspasari. 2004. Identifikasi habitat dan pemacuan stok sumber daya perairan karang di Teluk Saleh Nusa Tenggara Barat. Laporan Akhir. Proyek Riset Perikanan Tangkap Pusat Riset Perikanan Tangkap.

Heemstra, P.C. \& J.E. Randall. 1993. Groupers of the world. FAO Species Catalogue.

Kuiter, R.H. 1992. Tropical reef-fishes of the Western Pacific. Indonesia and Adjacent Waters.

Lazuardi, M.E. \& M.S. Wijoyo. 1999. Kebijakan dan strategi pengelolaan terumbu karang Indonesia. Prosiding Lokakarya Pengelolaan dan IPTEK Terumbu Karang Indonesia. LIPI-COREMAP. Jakarta. (215-221).

Subani, W. \& H.R. Barus. 1988. Alat penangkapan ikan dan udang laut di Indonesia. Jakarta. (113114). 


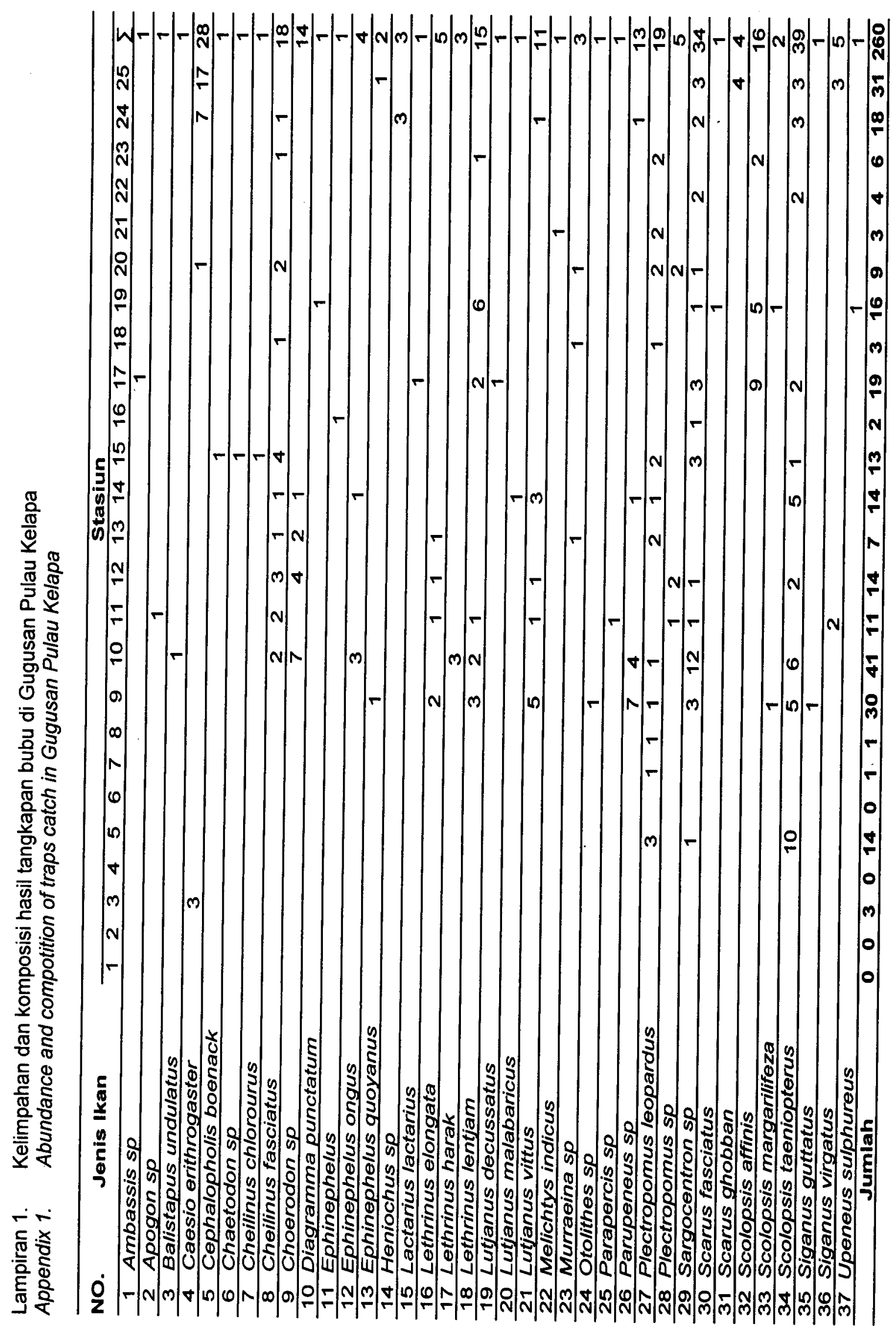




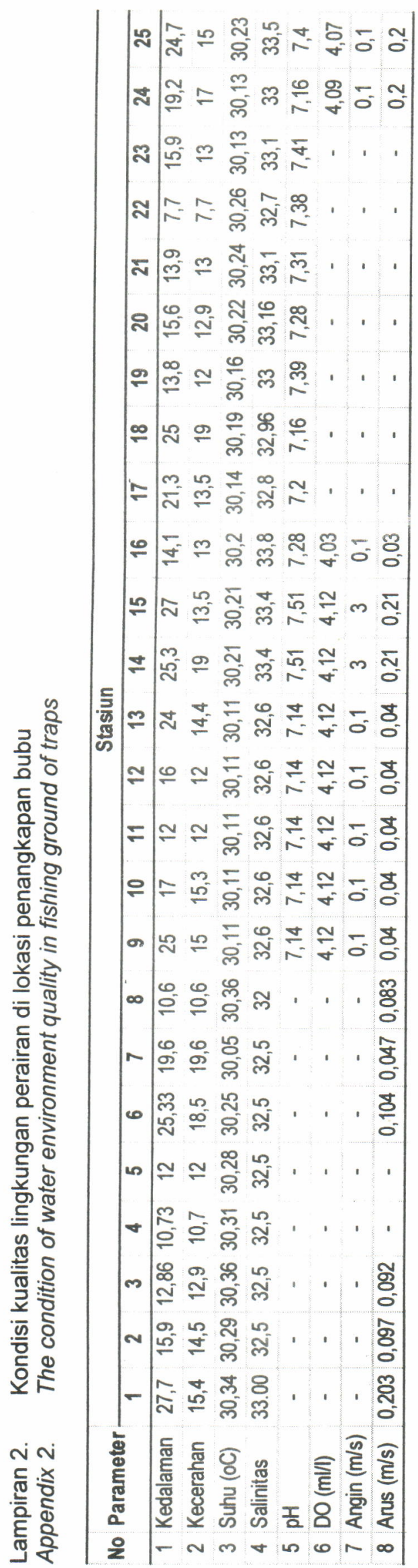

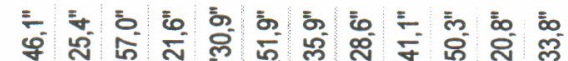

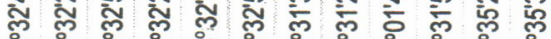
\& \& \& \& \& \& \& \& \& \& \&

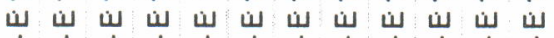
क กิ่

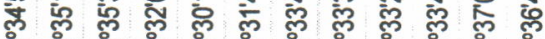

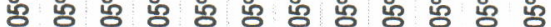
is is is is is is is is is is is is

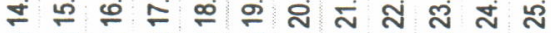
든 $\frac{5}{5}$. 密 ๘ ๗ 爱

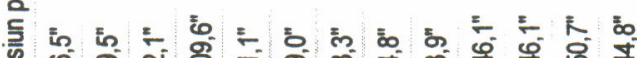

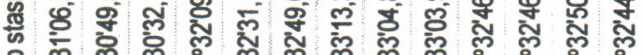

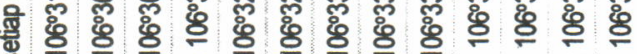

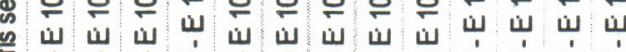
员 \&

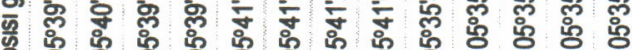

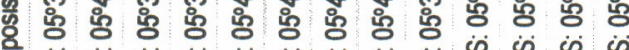
I. is is is is is is is is is is is is is

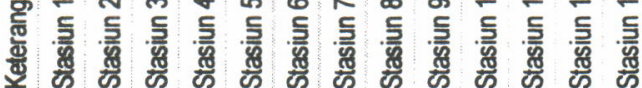


